\title{
Preparation and Quality Evaluation of Dehydrated Carrot and Onion Slices
}

Naimish Gupta and Shukla RN *

Department of Food Process Engineering, Sam Higginbottom University of Agriculture Technology \& Sciences, Allahabad, Uttar Pradesh, India

\begin{abstract}
Studies were conducted to determine the effect of different drying temperatures on the carrot and onion slices that were blanched with hot water and potassium meta bisulphite (KMS) then dipped in $0.25 \%$ for 20 min. Pre-treated to drying carrot and onion slices were dehydrated in cabinet tray dryer at four different temperatures viz. $50^{\circ} \mathrm{C}, 60^{\circ} \mathrm{C}, 70^{\circ} \mathrm{C}$ and $80^{\circ} \mathrm{C}$. Dehydrated products were then packed in LDPE and stored at ambient temperatures. The products were analysed for physico-chemical, microbial and sensory attributes at regular interval of 0 days, 15 days and 30 days during one-month storage period, the results were compared with the control sample. It was observed that moisture content and rehydration ratio increased during storage period but moisture content showed decreasing trend with increasing temperatures. There was decrease in $\beta$-carotene, Vitamin A content and organoleptic properties. However, no significant effect on ash content was observed during storage. The treated samples showed better nutritive value than the control sample. Finished product had no mould count which means the product remained microbiologically sterile during entire storage period. It was observed that the products dehydrated at $50^{\circ} \mathrm{C}$ and $60^{\circ} \mathrm{C}$ were best among all the samples.
\end{abstract}

Keywords: KMS; Blanching; Tray drying; Dehydration ratio; Rehydration ratio; Low density polyethylene

\section{Introduction}

Vegetables constitute an important item of human diet. They are plant or parts of plant that are used as food. Vegetables are important in improving the acceptability of the meal, because of innumerable shades of colour, flavour and texture they contribute. The minimum daily requirement of vegetable is about $284 \mathrm{~g}$ per head i.e., 20 percent of the total food requirement of an adult, it is more in case of vegetarians. India is one of the horticulturally rich countries of world taking second position next to china with regard to vegetable production. About 46.97 million tonnes of fresh fruits and 110.67 million tonnes of vegetables are grown in nearly 9 million hectares. Only 70 percent of horticultural crops are effectively utilized and 30 percent of these account for postharvest losses.

Drying is one of the most relevant and challenging processes of food industry, since a great number of food products are subjected to at least one drying step during its production. Dehydration or drying of foods is described as any process that involves thermal removal of volatile substances to obtain a dry solid [1]. The main purposes of drying crops are to increase its shelf life, to better its quality, to simplify the handling, storage and transport of the products and also to prepare the product to subsequent processes. Moringa Oleifera is native to some parts of Africa and Asia and it is the sole genus in the flowering plant family Moringaceae. Moringa is full of nutrients and vitamins and is good for both human and animal consumption. It is also a useful source of medicines. Drying of Agricultural crops is done in most farms by sun-drying. This results into contamination by insects and dust. Therefore, there is need to introduce the use of mechanical dryers provided that the nutritional characteristics would be retained better than using sun-drying method [2].

Being seasonal, as well as perishable due to high moisture content, carrots and onion are available in plenty only at a particular period of the years. During the peak season, due to abundant supply of carrots and onion the selling price becomes too low, leading to heavy losses to the growers. To preserve the carrots over a period of long time for use during off-seasons, dehydration is one of the most important methods, because it lowers the cost of packaging, storage and transportation by reducing both the weight and volume of the final product [3]
Carrot (Daucus carota) is an important vegetable, which has high nutritional value and utility. Carrot belongs to the family Umbelli ferae, genus Daucus, species Carota, and is one of the important root crops cultivated throughout the world for its fleshy edible roots cool season root vegetable grown extensively in various countries particularly during winter season in tropical regions. It finds wide application in day to day use for making carrot juice, carrot powder, terminated carrot sweetmeats, soups, stews carrot flakes etc. Carrot is known for its nutrient content viz., carotene and carotenoids, besides appreciable amounts of vitamins B1, B2, B6 and B12 vitamins and minerals. Hence, carrots occupy an important place in root vegetables for their multifaceted application, which in turn, results in the development of various processing operations for making different products and/or to extend shelf-life. Fresh carrots cannot be stored for more than 3-4 days under ordinary conditions, but shelf-life can be extended to 7-8 months if stored in crates covered with perforated plastic film at $0^{\circ} \mathrm{C}$ and 93-96 per cent relative humidity [4].

Onion belongs to the lily family amaryllidaceae, genus allium, species a. cepa, such as garlic and leeks. Dehydrated onion can be presented in powder, chunks, granules or slices. Its applications consider manufacturing of condiments, dehydrated or added to rehydrated meals. Dehydrated onion is used as condiment and flavouring agent in manufacturing of tomato ketchups, sauces, salad, pickles, chutneys, meat sausages, masala bread and buns, breakfast foods, etc. Dehydrated garlic is used for aids in digestion and for absorption of food having antiemetic and antiseptic properties and in some medicinal formulations. Allium crops are the most indispensable

*Corresponding author: Shukla RN, Department of Food Process Engineering, Sam Higginbottom University of Agriculture Technology and Sciences, Allahabad-211007, Uttar Pradesh, India, Tel: 09412397290; E-mail: rama shukla@shiats.edu.in

Received August 07, 2017; Accepted August 28, 2017; Published September 04, 2017

Citation: Gupta N, Shukla RN (2017) Preparation and Quality Evaluation of Dehydrated Carrot and Onion Slices. J Food Process Technol 8: 692. doi: 10.4172/2157-7110.1000692

Copyright: (C) 2017 Gupta N, et al. This is an open-access article distributed under the terms of the Creative Commons Attribution License, which permits unrestricted use, distribution, and reproduction in any medium, provided the original author and source are credited. 
vegetable crops used as condiments in most Ethiopian cuisine. Among them, onion rightly called "queen of kitchen", belongs to the family Alliaceae and considered as one of the most important vegetable and spice crops produced in large scale in Ethiopia and cultivated during the dry and rainy seasons [5].

\section{Methodology}

\section{Collection of carrot and onion samples}

Properly matured carrots were selected for the purpose. Carrots and onions should not have blemish on surface or any mechanical damage. Damaged carrots and onions may lead to contamination. Unripe carrots and onions might affect the moisture loss in process so they were not used.

Slices: Carrot and onion slices for blanching and further process. Main purpose of slices was to give carrots and onions a uniform shape and size throughout experiment.

\section{Pre-treatment}

Blanching: Principle for blanching is to inactivate the enzyme present in food commodity. Time and temperature combination for carrots and onions is $95^{\circ} \mathrm{C}$ for $2-3$ minutes. Carrots and onions was tied in muslin cloth and dipped in $95^{\circ} \mathrm{C}$ for $2-3$ minutes. After blanching they was cooled to room temperature. Free surface moisture was removed by sieving. In blanching of carrots and onions, leaching was found along with enzyme inactivation. So, slight weight loss obtained.

Potassium meta bisulphite (KMS): Carrot and onion was dipped in $0.25 \%$ KMS by weight for 20 mins. KMS was used as a preservative and thus increases the shelf life of slices.

Cabinet tray drying: Tray drying was done to dehydrate carrot and onion slices for different dehydration temperatures was taken as $50^{\circ} \mathrm{C}$, $60^{\circ} \mathrm{C}, 70^{\circ} \mathrm{C}$ and $80^{\circ} \mathrm{C}$

Collection of dried carrots and onions: Dried carrots and onions was collected and thus packaged in LDPE.

\section{Physico-chemical analysis}

Moisture content (\%): Moisture was determined according to the hot air oven method described by AOAC [6].

Moisture content $=\frac{W_{1}-W_{2}}{W_{1}-W} \times 100$

Where,

$\mathrm{W}=$ weight of empty petri plate, $\mathrm{g}$

$\mathrm{W}_{1}$ =weight of petri plate + slice before drying, $\mathrm{g}$

$\mathrm{W}_{2}=$ weight of petri plate + slice after drying, $\mathrm{g}$

Total ash content (\%): The ash was estimated according to the method described by Ranganna [7].

$$
\text { Ash content }(100)=\frac{W_{2}-W_{1}}{W} \times 100
$$

Where,

$$
\begin{aligned}
& \mathrm{W}=\text { weight of sample, } \mathrm{g} \\
& \mathrm{W}_{1}=\text { weight of crucible, } \mathrm{g} \\
& \mathrm{W}_{2}=\text { weight of crucible }+ \text { Ash, } \mathrm{g}
\end{aligned}
$$

Dehydration ratio: Dehydration ratio was calculated by taking the weights of sample before drying and the weight of sample after drying [8].

$$
\text { Dehydration ratio }=\frac{W_{2}}{W_{1}} \times 100
$$

Where,

$$
\begin{aligned}
& \mathrm{W}_{2}=\text { Weight of sample after drying } \\
& \mathrm{W}_{1}=\text { Weight of sample before drying }
\end{aligned}
$$

Rehydration ratio: Dehydrated slices were evaluated for rehydration ratio to find the reconstitution of dried sample using the following formula [7].

$$
\text { Rehydration ratio }=\frac{W_{2}}{W_{1}} \times 100
$$

Where,

$$
\begin{aligned}
& \mathrm{W}_{2}=\text { Weight of rehydrated sample, } \mathrm{g} \\
& \mathrm{W}_{1}=\text { Weight of the dehydrated sample, } \mathrm{g}
\end{aligned}
$$

Beta carotene content and vitamin $\mathrm{A}(\mu \mathrm{g} / 100 \mathrm{~g})$ : Reagents: Acetone, anhydrous sodium sulphate, petroleum ether. $5 \mathrm{~g}$ of fresh sample was taken and crushed in 10-15 ml acetone, adding few crystals of anhydrous sodium sulphate, with the help of pestle and mortar. The supernatant was decanted into the beaker. The process was reported twice and transferred the combined supernatant to a separatory funnel, adding 10-15 ml petroleum ether and mix thoroughly. Two layers was separated and the lower layer was discarded and upper layer was collected in a $100 \mathrm{ml}$ with petroleum ether and optical density was recorded using petroleum ether as blank [9].

Calculation:

$$
\beta-\operatorname{carotene}(\mu / g)=\frac{O . D \times 13.9 \times 104 \times 100}{\text { Wt.of Sample } \times 560 \times 1000}
$$

Vitamin A content: The vitamin A was estimated according to the method described by Suman and Kumari [10].

$$
\text { Vita } \min A(I . U)=\frac{\beta-\text { carotene }(\mu g)}{100}
$$

\section{Microbiological analysis}

Dehydrated carrots and onions have too low moisture content to support even the growth of moulds. If, however these products become moistened above the minimum of microbial growth, growth was flow. A little moistening was permit only the growth of moulds. Moulds are thus most common and most important cause of spoilage.

\section{Results and Discussion}

The result obtained from the present investigation as well as relevant discussion have summarized under following:

\section{Effect of temperature on moisture content (\%) of dehydrated carrot slices during storage period}

The product was prepared by processing it by different temperatures followed by storage at ambient temperature. Moisture content was calculated on the $0^{\text {th }}$ day. The effect of storage condition on the moisture content was evaluated after every 15 days during a period of one month. The results showed that moisture content decreased with the increase in temperature as there is more evaporation of the moisture 
at higher temperature. Also, the moisture content increased during the storage period, the reason may be due to the ingress of moisture through the packaging material. The results obtained are shown in Table 1, the highest moisture content for carrot was 5.21\% present in sample dehydrated at $50^{\circ} \mathrm{C}$ and lowest i.e., $4.98 \%$ was recorded in the sample dehydrated at $80^{\circ} \mathrm{C}$ [11].

\section{Effect of temperature on moisture content (\%) of dehydrated onion slices during storage period}

The product was prepared by processing it by different temperatures followed by storage at ambient temperature. Moisture content was calculated on the zeroth day. The effect of storage condition on the moisture content was evaluated after every 15 days during a period of one month. The results showed that moisture content decreased with the increase in temperature as there is more evaporation of the moisture at higher temperature. Also, the moisture content increased during the storage period, the reason may be due to the ingress of moisture through the packaging material. The results obtained are shown in Table 2, the highest moisture content for onion slices was $7.87 \%$ present in sample dehydrated at $50^{\circ} \mathrm{C}$ and lowest i.e., $7.73 \%$ was recorded in the sample dehydrated at $80^{\circ} \mathrm{C}$.

\section{Effect of temperature on ash content (\%) of dehydrated carrot slices during storage period}

The ash content was obtained by incineration of the sample at $550^{\circ} \mathrm{C}$ in muffle furnace, at this high temperature all the organic component in the samples burn out and inorganic component is left. The results obtained are given in Table 3 , the results showed that there was difference in ash content of sample treated at different temperatures. During storage, the ash content decreased slightly, this may be due to the increase in moisture content with the increase in storage period. The highest ash content in carrot was present in the sample dehydrated at $50^{\circ} \mathrm{C}$ i.e., $0.47 \%$ and lowest ash content $0.44 \%$ was found in the sample dehydrated at $80^{\circ} \mathrm{C}$ [12].

\begin{tabular}{|c|c|c|c|c|c|c|c|c|}
\hline \multicolumn{9}{|c|}{ Moisture Content (\%) of Carrot } \\
\hline \multirow{2}{*}{$\begin{array}{c}\text { Tempera- } \\
\text { ture }\end{array}$} & \multicolumn{4}{|c|}{ Control Sample } & \multicolumn{4}{|c|}{ Treated Sample } \\
\hline & 0 day & 15 days & $\begin{array}{c}30 \\
\text { days }\end{array}$ & Mean & 0 Day & 15 Days & 30 Days & Mean \\
\hline $50^{\circ} \mathrm{C}$ & $4 . .85$ & 5.06 & 5.27 & 5.06 & 5.21 & 5.4 & 5.62 & 5.41 \\
\hline $60^{\circ} \mathrm{C}$ & 4.77 & 4.98 & 5.21 & 4.98 & 5.13 & 5.35 & 5.54 & 5.34 \\
\hline $70^{\circ} \mathrm{C}$ & 4.71 & 4.91 & 5.16 & 4.92 & 5.07 & 5.26 & 5.48 & 5.27 \\
\hline $80^{\circ} \mathrm{C}$ & 4.65 & 4.85 & 5.09 & 4.86 & 4.98 & 5.17 & 5.39 & 5.18 \\
\hline Mean & 4.74 & 4.95 & 5.18 & & 5.09 & 5.29 & 5.50 & \\
\hline Result & $S$ & $S$ & S & & $\mathrm{S}$ & $S$ & $S$ & \\
\hline S. Ed. ( \pm ) & 0.025 & 0.058 & 0.037 & & 0.009 & 0.018 & 0.006 & \\
\hline C.D.at 5\% & 0.052 & 0.123 & 0.078 & & 0.019 & 0.038 & 0.012 & \\
\hline
\end{tabular}

Table 1: Effect of temperature on moisture content of dehydrated carrot slices during storage period.

\begin{tabular}{|c|c|c|c|c|c|c|c|c|}
\hline \multicolumn{9}{|c|}{ Moisture Content (\%) of Onion } \\
\hline \multirow[b]{2}{*}{$\begin{array}{c}\text { Tempera- } \\
\text { ture }\end{array}$} & \multicolumn{4}{|c|}{ Control Sample } & \multicolumn{4}{|c|}{ Treated Sample } \\
\hline & 0 day & 15 days & $\begin{array}{c}30 \\
\text { days }\end{array}$ & Mean & 0 Day & 15 Days & $\begin{array}{c}30 \\
\text { Days }\end{array}$ & Mean \\
\hline $50^{\circ} \mathrm{C}$ & 7.23 & 7.44 & 7.67 & 7.44 & 7.87 & 8.07 & 8.28 & 8.07 \\
\hline $60^{\circ} \mathrm{C}$ & 7.18 & 7.38 & 7.61 & 7.39 & 7.83 & 8.02 & 8.24 & 8.03 \\
\hline $70^{\circ} \mathrm{C}$ & 7.13 & 7.36 & 7.59 & 7.36 & 7.78 & 7.96 & 8.19 & 7.97 \\
\hline $80^{\circ} \mathrm{C}$ & 7.08 & 7.31 & 7.55 & 7.31 & 7.73 & 7.91 & 8.15 & 7.93 \\
\hline Mean & 7.15 & 7.37 & 7.60 & & 7.80 & 7.99 & 8.21 & \\
\hline Result & $\mathrm{S}$ & $\mathrm{S}$ & $S$ & & $\mathrm{~S}$ & $S$ & $\mathrm{~S}$ & \\
\hline S. Ed. ( $( \pm)$ & 0.035 & 0.024 & 0.006 & & 0.042 & 0.007 & 0.037 & \\
\hline C.D.at $5 \%$ & 0.075 & 0.050 & 0.013 & & 0.090 & 0.014 & 0.038 & \\
\hline
\end{tabular}

Table 2: Effect of temperature on moisture content of dehydrated onion slices during storage period.

\begin{tabular}{|c|c|c|c|c|c|c|c|c|}
\hline \multicolumn{9}{|c|}{ Ash Content (\%) of Carrot } \\
\hline \multirow{2}{*}{$\begin{array}{l}\text { Tempera- } \\
\text { ture }\end{array}$} & \multicolumn{4}{|c|}{ Control Sample } & \multicolumn{4}{|c|}{ Treated Sample } \\
\hline & 0 Day & 15 Days & 30 Days & Mean & 0 Day & 15 Days & 30 Days & Mean \\
\hline $50^{\circ} \mathrm{C}$ & 0.28 & 0.27 & 0.26 & 0.27 & 0.47 & 0.46 & 0.45 & 0.46 \\
\hline $60^{\circ} \mathrm{C}$ & 0.27 & 0.26 & 0.25 & 0.26 & 0.46 & 0.45 & 0.44 & 0.45 \\
\hline $70^{\circ} \mathrm{C}$ & 0.26 & 0.25 & 0.24 & 0.25 & 0.45 & 0.44 & 0.43 & 0.44 \\
\hline $80^{\circ} \mathrm{C}$ & 0.25 & 0.24 & 0.23 & 0.24 & 0.44 & 0.43 & 0.42 & 0.43 \\
\hline Mean & 0.26 & 0.25 & 0.24 & & 0.45 & 0.44 & 0.43 & \\
\hline Result & $S$ & $\mathrm{~S}$ & $S$ & & $\mathrm{~S}$ & $S$ & $S$ & \\
\hline S. Ed. ( \pm$)$ & 0.007 & 0.007 & 0.005 & & 0.008 & 0.008 & 0.004 & \\
\hline C.D. at $5 \%$ & 0.016 & 0.014 & 0.010 & & 0.016 & 0.017 & 0.008 & \\
\hline
\end{tabular}

Table 3: Effect of temperature on ash content of dehydrated carrot slices during storage period.

\begin{tabular}{|c|c|c|c|c|c|c|c|c|}
\hline \multicolumn{9}{|c|}{ Ash Content (\%) of Onion } \\
\hline \multirow[b]{2}{*}{ Treatments } & \multicolumn{4}{|c|}{ Control Sample } & \multicolumn{4}{|c|}{ Treated Sample } \\
\hline & 0 Day & $\begin{array}{c}15 \\
\text { Days }\end{array}$ & $\begin{array}{c}30 \\
\text { Days }\end{array}$ & Mean & 0 Day & $\begin{array}{c}15 \\
\text { Days }\end{array}$ & $\begin{array}{c}30 \\
\text { Days }\end{array}$ & Mean \\
\hline $50^{\circ} \mathrm{C}$ & 0.24 & 0.23 & 0.22 & 0.23 & 0.43 & 0.42 & 0.41 & 0.42 \\
\hline $60^{\circ} \mathrm{C}$ & 0.23 & 0.22 & 0.21 & 0.22 & 0.42 & 0.42 & 0.41 & 0.41 \\
\hline $70^{\circ} \mathrm{C}$ & 0.22 & 0.21 & 0.20 & 0.21 & 0.41 & 0.40 & 0.39 & 0.40 \\
\hline $80^{\circ} \mathrm{C}$ & 0.21 & 0.20 & 0.19 & 0.20 & 0.40 & 0.39 & 0.38 & 0.39 \\
\hline Mean & 0.25 & 0.21 & 0.20 & & 0.41 & 0.40 & 0.39 & \\
\hline Result & S & S & S & & $\mathrm{S}$ & S & $\mathrm{S}$ & \\
\hline S. Ed. ( \pm ) & 0.006 & 0.005 & 0.005 & & 0.007 & 0.008 & 0.004 & \\
\hline C.D. at $5 \%$ & 0.013 & 0.011 & 0.010 & & 0.015 & 0.017 & 0.008 & \\
\hline
\end{tabular}

Table 4: Effect of temperature on ash content of dehydrated onion slices during storage period.

\section{Effect of temperature on ash content (\%) of dehydrated onion slices during storage period}

The ash content was obtained by incineration of the sample at $550^{\circ} \mathrm{C}$ in muffle furnace, at this high temperature all the organic component in the samples burn out and inorganic component is left. The results obtained are given in Table 4, the results showed that there was difference in ash content of sample treated at different temperatures. During storage, the ash content decreased slightly, this may be due to the increase in moisture content with the increase in storage period. The highest ash content in onion was present in the sample dehydrated at $50^{\circ} \mathrm{C}$ i.e., $0.43 \%$ and lowest ash content $0.40 \%$ was found in the sample dehydrated at $80^{\circ} \mathrm{C}$.

\section{Effect of drying temperature on weight loss of fresh carrot} and onion slices

The weight loss in the sample upon drying is due to loss in moisture content. As moisture forms an important component of fresh vegetables, so upon drying moisture content is reduce thereby reducing the weight. The weight loss was calculated from initial weight of the blanched carrot slices and samples which were dried at $50^{\circ} \mathrm{C}, 60^{\circ} \mathrm{C}$, $70^{\circ} \mathrm{C}$ and $80^{\circ} \mathrm{C}$ (Table 5). The weight loss was calculated for 0 min up to 5 hours for every one hour. Similarly, the weight loss was calculated from initial weight of the blanched onion slices during drying at $50^{\circ} \mathrm{C}$, $60^{\circ} \mathrm{C}, 70^{\circ} \mathrm{C}$ and $80^{\circ} \mathrm{C}, 0$ mins up to 5 hours in every one-hour weight of sample [13].

\section{Effect of drying temperature on dehydration ratio of carrot slices}

The dehydration ratio calculated from initial weight of carrot during cabinet type tray drying at $50^{\circ} \mathrm{C}, 60^{\circ} \mathrm{C}, 70^{\circ} \mathrm{C}$ and $80^{\circ} \mathrm{C}$ (blanching and KMS) is shown in Table 6, The results showed that dehydration ratio decreased with the increase in temperature as there occurs more evaporation of the moisture at higher temperature [13]. 
Citation: Gupta N, Shukla RN (2017) Preparation and Quality Evaluation of Dehydrated Carrot and Onion Slices. J Food Process Technol 8: 692. doi: $10.4172 / 2157-7110.1000692$

Page 4 of 6

\section{Effect of drying temperature on dehydration ratio of onion slices}

The dehydration ratio calculated from initial weight of onion during cabinet type tray drying at $50^{\circ} \mathrm{C}, 60^{\circ} \mathrm{C}, 70^{\circ} \mathrm{C}$ and $80^{\circ} \mathrm{C}$ (blanching and KMS) is shown in Table 7. The results showed that dehydration ratio decreased with the increase in temperature as there occurs more evaporation of the moisture at higher temperature.

\begin{tabular}{|c|c|c|c|c|c|c|c|c|}
\hline \multicolumn{9}{|c|}{ Weight Loss } \\
\hline & \multicolumn{4}{|c|}{ Carrot(g) } & \multicolumn{4}{|c|}{ Onion(g) } \\
\hline Time(min) & at $50^{\circ} \mathrm{C}$ & at $60^{\circ} \mathrm{C}$ & $\begin{array}{c}\text { at } \\
70^{\circ} \mathrm{C}\end{array}$ & $\begin{array}{c}\text { at } \\
80^{\circ} \mathrm{C}\end{array}$ & at $50^{\circ} \mathrm{C}$ & $\begin{array}{c}\text { at } \\
60^{\circ} \mathrm{C}\end{array}$ & $\begin{array}{c}\text { at } \\
70^{\circ} \mathrm{C}\end{array}$ & $\begin{array}{l}\text { at } \\
80^{\circ} \mathrm{C}\end{array}$ \\
\hline 0 & 100 & 100 & 100 & 100 & 100 & 100 & 100 & 100 \\
\hline 60 & 40.5 & 38.46 & 36.31 & 34.28 & 38.45 & 36.46 & 33.85 & 31.32 \\
\hline 120 & 24.4 & 23.68 & 21.50 & 20.45 & 22.45 & 21.05 & 19.15 & 18.32 \\
\hline 180 & 19.85 & 19.79 & 19.75 & 19.71 & 17.65 & 17.54 & 17.42 & 17.31 \\
\hline 240 & 14.93 & 14.81 & 14.76 & 14.49 & 12.23 & 12.18 & 12.15 & 12.13 \\
\hline \multirow[t]{2}{*}{300} & 4.69 & 14.67 & 14.48 & 14.32 & 11.75 & 11.69 & 11.62 & 11.58 \\
\hline & Result & $\begin{array}{l}\text { S. Ed. } \\
( \pm)\end{array}$ & $\begin{array}{c}\text { C.D. at } \\
5 \%\end{array}$ & & Result & $\begin{array}{c}\text { S. Ed. } \\
( \pm)\end{array}$ & $\begin{array}{c}\text { C.D. at } \\
5 \%\end{array}$ & \\
\hline Due to temp & NS & 0.816 & 1.730 & & NS & 0.927 & 1.966 & \\
\hline Due to Time & $\mathbf{s}$ & 0.666 & 1.412 & & s & 0.757 & 1.605 & \\
\hline
\end{tabular}

Table 5: Effect of drying temperature on weight loss of fresh carrot and onion slices.

\begin{tabular}{|c|c|c|c|}
\hline \multicolumn{4}{|c|}{ Dehydration Ratio of Carrot } \\
\hline Temperature & $\begin{array}{c}\text { Weight of the sample } \\
\text { before drying (g) B }\end{array}$ & $\begin{array}{c}\text { Weight of the sample } \\
\text { after drying (g) A }\end{array}$ & $\begin{array}{c}\text { Dehydration } \\
\text { ratio(B/A) }\end{array}$ \\
\hline $\begin{array}{c}\text { Control Sample } \\
50^{\circ} \mathrm{C}\end{array}$ & 950 & 103 & 0.108 \\
\hline $\begin{array}{c}\text { Treated Sample } \\
50^{\circ} \mathrm{C}\end{array}$ & 900 & 105 & 0.116 \\
\hline $\begin{array}{c}\text { Control Sample } \\
60^{\circ} \mathrm{C}\end{array}$ & 1200 & 116 & 0.096 \\
\hline $\begin{array}{c}\text { Treated Sample } \\
60^{\circ} \mathrm{C}\end{array}$ & 1100 & 115 & 0.104 \\
\hline $\begin{array}{c}\text { Control Sample } \\
70^{\circ} \mathrm{C}\end{array}$ & 900 & 81 & 0.090 \\
\hline $\begin{array}{c}\text { Treated Sample } \\
70^{\circ} \mathrm{C}\end{array}$ & 1000 & 98 & 0.098 \\
\hline $\begin{array}{c}\text { Control Sample } \\
80^{\circ} \mathrm{C}\end{array}$ & 850 & 68 & 0.080 \\
\hline $\begin{array}{c}\text { Treated Sample } \\
80^{\circ} \mathrm{C}\end{array}$ & 800 & 71 & 0.088 \\
\hline
\end{tabular}

Table 6: Effect of drying temperature on dehydration ratio of carrot slices.

\begin{tabular}{|c|c|c|c|}
\hline \multicolumn{4}{|c|}{ Dehydration Ratio of Onion } \\
\hline Temperature & $\begin{array}{c}\text { Weight of the sample } \\
\text { before drying (g) B }\end{array}$ & $\begin{array}{c}\text { Weight of the sample } \\
\text { after drying (g) A }\end{array}$ & $\begin{array}{c}\text { Dehydration } \\
\text { ratio (B/A) }\end{array}$ \\
\hline $\begin{array}{c}\text { Control Sample } \\
50^{\circ} \mathrm{C}\end{array}$ & 1050 & 104 & 0.099 \\
\hline $\begin{array}{c}\text { Treated Sample } \\
50^{\circ} \mathrm{C}\end{array}$ & 1100 & 115 & 0.104 \\
\hline $\begin{array}{c}\text { Control Sample } \\
60^{\circ} \mathrm{C}\end{array}$ & 1100 & 105 & 0.095 \\
\hline $\begin{array}{c}\text { Treated Sample } \\
60^{\circ} \mathrm{C}\end{array}$ & 1200 & 118 & 0.098 \\
\hline $\begin{array}{c}\text { Control Sample } \\
70^{\circ} \mathrm{C}\end{array}$ & 1150 & 100 & 0.086 \\
\hline $\begin{array}{c}\text { Treated Sample } \\
70^{\circ} \mathrm{C}\end{array}$ & 1200 & 107 & 0.089 \\
\hline $\begin{array}{c}\text { Control Sample } \\
80^{\circ} \mathrm{C}\end{array}$ & 900 & 72 & 0.080 \\
\hline $\begin{array}{c}\text { Treated Sample } \\
80^{\circ} \mathrm{C}\end{array}$ & 1000 & 84 & 0.084 \\
\hline
\end{tabular}

Table 7: Effect of drying temperature on dehydration ratio of onion slices.

\begin{tabular}{|c|c|c|c|c|c|c|}
\hline \multicolumn{7}{|c|}{ Rehydration Ratio of Carrot } \\
\hline \multirow[b]{2}{*}{ Temperature } & \multicolumn{3}{|c|}{ Control Sample } & \multicolumn{3}{|c|}{ Treated Sample } \\
\hline & $\begin{array}{c}\text { After } 30 \\
\text { min }\end{array}$ & $\begin{array}{c}\text { After } 60 \\
\text { min }\end{array}$ & Mean & $\begin{array}{c}\text { After } 30 \\
\text { min }\end{array}$ & $\begin{array}{c}\text { After } 60 \\
\text { min }\end{array}$ & Mean \\
\hline $50^{\circ} \mathrm{C}$ & 5.95 & 5.98 & 5.96 & 6.23 & 6.27 & 6.25 \\
\hline $60^{\circ} \mathrm{C}$ & 6.01 & 6.05 & 6.03 & 6.29 & 6.33 & 6.31 \\
\hline $70^{\circ} \mathrm{C}$ & 6.07 & 6.11 & 6.09 & 6.35 & 6.39 & 6.37 \\
\hline $80^{\circ} \mathrm{C}$ & 6.12 & 6.16 & 6.14 & 6.42 & 6.46 & 6.44 \\
\hline Mean & 6.03 & 6.07 & & 6.32 & 6.36 & \\
\hline Result & $S$ & $S$ & & $S$ & $\mathrm{~S}$ & \\
\hline S. Ed. ( \pm ) & 0.041 & 0.008 & & 0.011 & 0.014 & \\
\hline C.D. at $5 \%$ & 0.086 & 0.018 & & 0.023 & 0.031 & \\
\hline
\end{tabular}

Table 8: Effect of drying temperature on rehydration ratio of carrot slices.

\begin{tabular}{|c|c|c|c|c|c|c|}
\hline \multicolumn{7}{|c|}{ Rehydration Ratio of Onion } \\
\hline \multirow[b]{2}{*}{ Temperature } & \multicolumn{3}{|c|}{ Control Sample } & \multicolumn{3}{|c|}{ Treated Sample } \\
\hline & $\begin{array}{c}\text { After } 30 \\
\text { min }\end{array}$ & $\begin{array}{c}\text { After } 60 \\
\text { min }\end{array}$ & Mean & $\begin{array}{c}\text { After } 30 \\
\text { min }\end{array}$ & $\begin{array}{c}\text { After } 60 \\
\text { min }\end{array}$ & Mean \\
\hline $50^{\circ} \mathrm{C}$ & 6.34 & 6.37 & 6.35 & 6.62 & 6.65 & 6.63 \\
\hline $60^{\circ} \mathrm{C}$ & 6.39 & 6.42 & 6.40 & 6.67 & 6.68 & 6.67 \\
\hline $70^{\circ} \mathrm{C}$ & 6.45 & 6.49 & 6.47 & 6.71 & 6.73 & 6.72 \\
\hline $80^{\circ} \mathrm{C}$ & 6.49 & 6.52 & 6.50 & 6.76 & 6.78 & 6.77 \\
\hline Mean & 6.41 & 6.45 & & 6.69 & 6.71 & \\
\hline Result & $S$ & $S$ & & $S$ & $S$ & \\
\hline S. Ed. ( \pm ) & 0.025 & 0.009 & & 0.031 & 0.014 & \\
\hline C.D. at $5 \%$ & 0.054 & 0.19 & & 0.066 & 0.031 & \\
\hline
\end{tabular}

Table 9: Effect of drying temperature on rehydration ratio of onion slices.

\section{Effect of drying temperature on rehydration ratio of carrot slices}

The rehydration was carried out by immersing dried carrot slices in boiling water, maintained at four temperatures i.e., $50^{\circ} \mathrm{C}, 60^{\circ} \mathrm{C}, 70^{\circ} \mathrm{C}$, and $80^{\circ} \mathrm{C}$. Approximately $5 \mathrm{~g}$ of sample was added to $200 \mathrm{ml}$ of water, agitated and then allowed to rehydrate for 30 and $60 \mathrm{~min}$ time intervals and the contents were then filtered through filter paper. The weight of sample and the rehydration ratio is shown in Table 8 . After the $30 \mathrm{~min}$, the rehydration ratios of dehydrated carrots were found to be $6.23,6.29$, 6.35 and 6.42 respectively. After the $60 \mathrm{~min}$, the rehydration ratio was found to be slight increased i.e., $6.27,6.33,6.39$, and 6.46 respectively. The increase in the rehydration ratio was due to the absorption of water by the dried carrot slices. The rehydration ratio was seen less on $70^{\circ} \mathrm{C}$ and $80^{\circ} \mathrm{C}$ because of the high temperature due to which surface water was dried quickly and bound water was not dried properly [14,15].

\section{Effect of drying temperature on rehydration ratio of onion slices}

The rehydration was carried out by immersing dried onion slices in boiling water, maintained at four temperatures i.e., $50^{\circ} \mathrm{C}, 60^{\circ} \mathrm{C}, 70^{\circ} \mathrm{C}$, and $80^{\circ} \mathrm{C}$. Approximately $5 \mathrm{~g}$ of sample was added to $200 \mathrm{ml}$ of water, agitated and then allowed to rehydrate for 30 and $60 \mathrm{~min}$ time intervals and the contents were then filtered through filter paper. The weight of sample and the rehydration ratio is shown in Table 9 . After the $30 \mathrm{~min}$, the rehydration ratios of dehydrated onion were found to be $6.62,6.67$, 6.71 and 6.76 respectively. After the $60 \mathrm{~min}$, the rehydration ratio was found to be slight increased i.e., $6.65,6.68,6.73$, and 6.78 respectively. The increase in the rehydration ratio was due to the absorption of water by the dried onion slices. The rehydration ratio was seen less on $70^{\circ} \mathrm{C}$ and $80^{\circ} \mathrm{C}$ because of the high temperature due to which surface water was dried quickly and bound water was not dried properly

Effect of temperature on carotenoid content of dehydrated carrot slices during storage period $(\mu \mathrm{g} / 100 \mathrm{~g})$

The effect of different temperature time combination in $\beta$-carotene 


\begin{tabular}{|c|c|c|c|c|c|c|}
\hline \multicolumn{7}{|c|}{ Carotenoid Content } \\
\hline \multicolumn{4}{|c|}{ Treated Sample } & \multicolumn{3}{|c|}{ Control sample } \\
\hline Temperature & 0 Day & 15 Days & 30 Days & 0 Day & 15 Days & 30 Days \\
\hline $50^{\circ} \mathrm{C}$ & 55075.7 & 55073.6 & 55072.5 & 50075.5 & 50074.6 & 50073.5 \\
\hline $60^{\circ} \mathrm{C}$ & 50061.7 & 50060.6 & 50058.6 & 45073.4 & 45072.6 & 45071.6 \\
\hline $70^{\circ} \mathrm{C}$ & 45061.7 & 45060.6 & 45059.6 & 40074.5 & 40073.6 & 40072.6 \\
\hline $80^{\circ} \mathrm{C}$ & 40087.3 & 40085.2 & 40084.1 & 35072.6 & 35071.2 & 35070.1 \\
\hline Mean & 47571.60 & 47570.10 & 47568.70 & 42574 & 42573 & 42571.95 \\
\hline Result & $S$ & $S$ & $S$ & $S$ & $S$ & $S$ \\
\hline S. Ed. ( \pm$)$ & 5.321 & 6.033 & 6.369 & 4.260 & 3.558 & 3.894 \\
\hline C.D. at $5 \%$ & 11.280 & 12.790 & 13.502 & 9.032 & 7.543 & 8.255 \\
\hline
\end{tabular}

Table 10: Effect of temperature on carotenoid content of dehydrated carrot slices during storage period $(\mu \mathrm{g} / 100 \mathrm{~g})$.

\begin{tabular}{|c|c|c|c|c|c|c|}
\hline \multicolumn{7}{|c|}{ Vitamin A Content } \\
\hline \multicolumn{4}{|c|}{ Treated Sample } & \multicolumn{3}{|c|}{ Control Sample } \\
\hline Temperature & 0 Day & 15 Days & 30 Days & 0 Day & 15 Days & 30 Days \\
\hline $50^{\circ} \mathrm{C}$ & 550.757 & 550.736 & 550.725 & 500.755 & 500.746 & 500.735 \\
\hline $60^{\circ} \mathrm{C}$ & 500.617 & 500.606 & 500.586 & 450.734 & 450.726 & 450.716 \\
\hline $70^{\circ} \mathrm{C}$ & 450.617 & 450.606 & 450.596 & 400.745 & 400.736 & 400.726 \\
\hline $80^{\circ} \mathrm{C}$ & 400.873 & 400.852 & 400.841 & 350.726 & 350.712 & 350.701 \\
\hline Mean & 475.716 & 475.70 & 475.687 & 425.74 & 425.73 & 425.71 \\
\hline Result & $S$ & $S$ & $S$ & $S$ & $S$ & $S$ \\
\hline S. Ed. ( \pm$)$ & 5.310 & 6.119 & 5.296 & 4.103 & 4.619 & 2.833 \\
\hline C.D. at $5 \%$ & 11.258 & 12.973 & 11.227 & 8.698 & 9.792 & 6.007 \\
\hline
\end{tabular}

Table 11: Effect of different temperatures on Vitamin A content of dehydrated carrot slices during storage period $(\mu \mathrm{g} / 100 \mathrm{~g})$.

\begin{tabular}{|c|c|c|}
\hline Physico-Chemical Properties & Carrot & Onion \\
\hline Moisture Content & $85.5 \%$ & $88.6 \%$ \\
\hline Ash Content & $0.30 \%$ & $0.26 \%$ \\
\hline B-Carotene Content & $75075.2 \mu \mathrm{g} / 100 \mathrm{~g}$ & - \\
\hline Vitamin A Content & $750.752 \mu \mathrm{g} / 100 \mathrm{~g}$ & - \\
\hline
\end{tabular}

Table 12: Physico-chemical properties of fresh carrot and onion $100 \mathrm{~g}$

content on $50^{\circ} \mathrm{C}, 60^{\circ} \mathrm{C}, 70^{\circ} \mathrm{C}, 80^{\circ} \mathrm{C}$ at 15 days interval during storage is shown in (Table 10). At $0^{\text {th }}$ day, $\beta$-carotene content of carrots dehydrated at $50^{\circ} \mathrm{C}, 60^{\circ} \mathrm{C}, 70^{\circ} \mathrm{C}, 80^{\circ} \mathrm{C}$ was found to be 55075.7 , $50061.7,45061.7$ and $40087.3 \mu \mathrm{g}$ respectively. After 15 days of storage, $\beta$-carotene value was found to be 55073.6, 50060.6, 45060.6 and $40085.2 \mu \mathrm{g}$ respectively. On critical evaluation of the result during storage it was found that $\beta$-carotene content decreased with increase in storage and temperature. Finally, after 30 days of storage, the values of $\beta$-carotene were $55072.5,50058.6,45059.6$ and $40084.1 \mu \mathrm{g}$ respectively. Carotenoids are the pigments which are sensitive to heat. Due to treatment, at different temperature thermal degradation occur there by reducing the carotenoids content [9].

\section{Effect of different temperatures on Vitamin A content of dehydrated carrot slices during storage period $(\mu \mathrm{g} / 100 \mathrm{~g})$}

The effect of different temperatures and storage period on vitamin A content of dehydrated carrot slices at $50^{\circ} \mathrm{C}, 60^{\circ} \mathrm{C}, 70^{\circ} \mathrm{C}, 80^{\circ} \mathrm{C}$, at regular interval of 15 days during storage is shown in Table $11.0^{\text {th }}$ day readings of vitamin A content of samples treated at $50^{\circ} \mathrm{C}, 60^{\circ} \mathrm{C}, 70^{\circ} \mathrm{r}$ and $80^{\circ} \mathrm{C}$ were found to be $550.757,500.617,450.617$ and $400.873^{\mu}$ g respectively. On $15^{\text {th }}$ day of storage, Vitamin A value was found to be 550.736, 500.606, 450.606, and $400.852 \mu$ g respectively. From the obtained results, it was found that the Vitamin A content decreased with increase in temperature as well as during storage period. On the $30^{\text {th }}$ day of storage study, the values of Vitamin A were 550.725, 500.586, 450.596 and $400.841 \mu \mathrm{g}$ respectively. Due to the thermal treatment (at different temperature) the Vitamin A content of dehydrated carrot slices decreases due to thermal degradation [16].

\section{Microbial analysis}

Dehydrated carrot and onion slices: Dehydrated products have such a restricted that there is little difficulty in preventing the growth of micro-organisms as long as they are kept dry. There moisture content is too low to support even the growth of moulds. If, however these products become moistened above the minimum of microbial growth, growth will follow. A little moistening will permit only the growth of moulds. Moulds are thus most common and most important cause of spoilage. So, the mould count at room temperature was studied for samples of dehydrated carrot and onion slices to study the accuracy in the microbial quality and also to determine the frequency of distribution within standard limits with interval of 0 days up to 30 days. But, there was no mould count seen for 30 days when pre-treated with blanching and KMS. Therefore, minimum shelf life is 30 days (Table 12).

\section{Conclusion}

From the results of this study it is concluded that the quality evaluation at different drying temperatures for carrot and onion slices showed similar trend or nature towards the storage conditions that were provided after packing in the LDPE for 30 days to observe the shelf life of dried carrot and onion slices. The temperatures were the most pronounced factors affecting moisture content, rehydration ratio, carotenoid content, vitamin A content of carrot and onion slices during tray drying. Results obtained showed that the effect of application of pre-treatment was significant on the initial moisture content of the carrot and onion slices and were found to be best as base material for the preparation of carrot and onion powder for the off-season. The dehydrated products will be of great use particularly in off season of carrot and dehydrated onion powder is primarily used for preparation of ready to make foods. No mould growth was observed during storage period. The Physico-chemical properties of carrot and onion slices were preserved in KMS treatment because KMS had some leaching effect on products due to the release of $\mathrm{SO}_{2}$ in water during treatment. On the basis of quality attributes, and sensory attributes especially colour and appearance the products were acceptable. However, there was difference in the overall acceptability of the product. Suggestions for future work.

\section{References}

1. Wankhade P, Sapkal R, Sapkal, V (2013) Drying characteristics of okra slices on drying in hot air dryer. Procedia Eng 51: 371-374.

2. Lasisi D, Balogun LA, Nasirudeen AR, Ogunsola FO, Adesola AA, et al. (2013) Comparative study of effects of drying methods on the quality of cocoa beans. Proceedings of The Nigerian Institution of Agricultural Engineers 34: 579-583.

3. Singh B, Panesar PS, Kennedy JF (2001) Optimization of osmotic dehydration process of carrot cubes in mixtures of sucrose and sodium chloride solutions. Europe Food Res.

4. Chadha KL (2002) Handbook of horticulture. Indian Council of Agriculture Research, New Delhi.

5. Rubatzky VE, Yamaguchi M (1997) World vegetable: Principles, production and nutritive values. International Thomson Publishing, New York, USA

6. AOAC (2006) Official methods of analysis and calculations moisture (M) Method 934.06 Fruits, Vegetables, and their Products, Association of Analytical Communities, Gaithersburg.

7. Ranganna S (2008) Handbook of analysis and quality control for fruit and vegetable products (2nd ed). Tata McGraw Hill, New Delhi.

8. Singh B, Kumar A, Gupta AK (2007) Study of mass transfer kinetics and effective diffusivity during osmotic dehydration of carrot cubes. J Food Eng 79 : 471-480. 
Citation: Gupta N, Shukla RN (2017) Preparation and Quality Evaluation of Dehydrated Carrot and Onion Slices. J Food Process Technol 8: 692. doi: $10.4172 / 2157-7110.1000692$

Page 6 of 6

9. Chen HE, Peng HY, Chen BH (1996) Stability of carotenoids and vitamin A during storage of carrot juice. Food Chem 57: 497-503.

10. Suman M, Krishna-Kumari K (2002) A study on sensory evaluation, betacarotene retention and shelf-life of dehydrated carrot products. J Food Sci Technol 39: 677-681.

11. Chakraverty $A$ (2003) Post-harvest technology of cereals, oilseeds and pulses. Oxford and IBH Publishing Co.Ltd, New Delhi.

12. Muhammad S, Sheikh SA, Khaskheli GS (2010) Effect of storage on the physicochemical characteristics of the mango (Mangifera indica L.) variety, Langra. Africa J Biotechnol 11: 9825-9828.
13. Kumar PG, Ramesh MN, Umesh Hebbar H (2006) Suitability of thin layer models for infrared hot air-drying of onion slices. J Food Technol 39: 700.

14. Mazza G (1983) Dehydration of carrots: Effects of pre-drying treatments on moisture transport and product quality. J Food Technol 18: 113-123.

15. Frederick JF (2000) Encyclopaedia of food science and technology. John Wiley and Sons Inc, New York.

16. Kumari S, Kumari NK, Jyothi J, Lavanya JL, Swarnalatha (2013) Study on drying behaviour of sapota (manilkara achras) in solar tray dryer and hot air cabinet dryer. J Environ Sci Toxic Food Technol. 